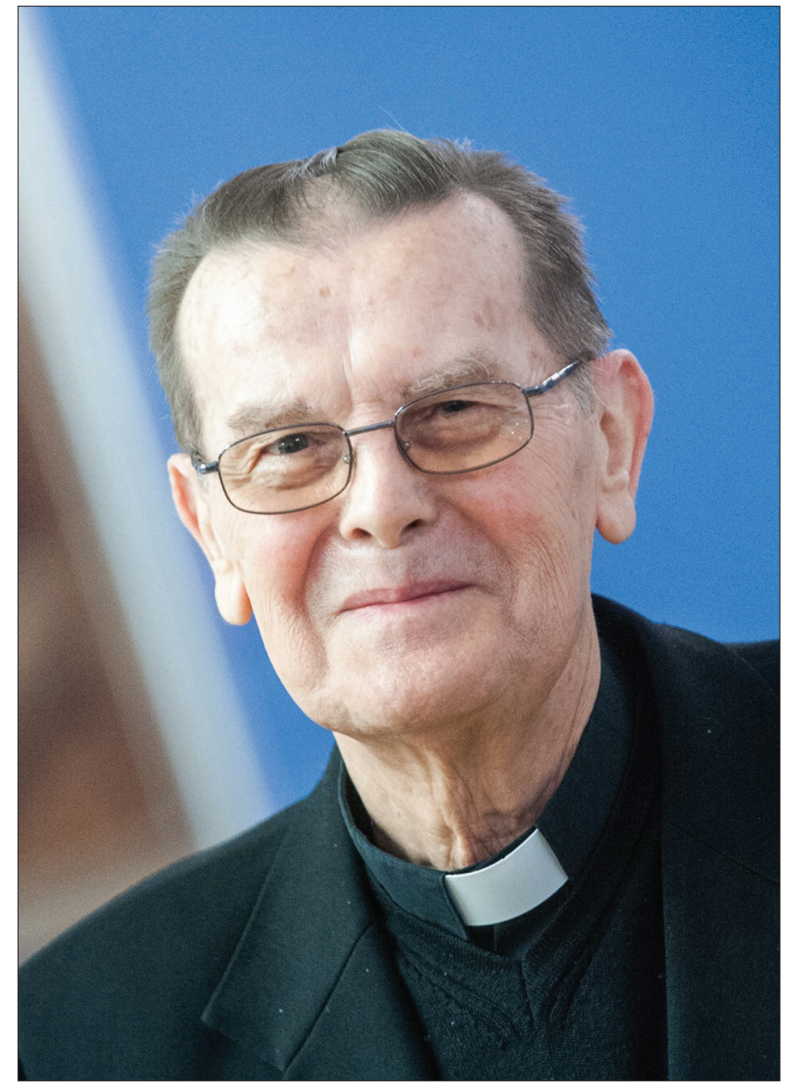

KS. PROF. DR HAB. HENRYK MISZTAL (1936-2020) 

$\mathrm{O}$

$\mathrm{R}$

STUDIA Z PRAWA WYZNANIOWEGO

Tom $24-2021$

DOI: https://doi.org/10.31743/spw.12956

PIOTR STANISZ*

ANETA M. ABRAMOWICZ ${ }^{* *}$

\section{KSIĄDZ PROFESOR HENRYK MISZTAL (1936-2020): CZŁOWIEK - KAPŁAN - UCZONY - NAUCZYCIEL}

Rev. Prof. Henryk Misztal (1936-2020):

Man - Priest - Scholar - Academic

Streszczenie: Niniejsze opracowanie jest wspomnieniem o ks. prof. dr. hab. Henryku Misztalu, który zmarł w dniu 28 października 2020 r., a jego celem jest upamiętnienie tego wybitnego naukowca, zaangażowanego nauczyciela, niestrudzonego wychowawcy pracowników nauki, a nadto gorliwego kapłana i dobrego człowieka. Swą naukową aktywność Ksiądz Profesor ściśle związał z Katolickim Uniwersytetem Lubelskim Jana Pawła II. Przez lata kierował pracami Katedry Prawa Wyznaniowego (której był kierownikiem) oraz Katedry Prawa Kanonizacyjnego (której był kuratorem). Pełnił też szereg innych ważnych funkcji uniwersyteckich. Był m.in. prodziekanem (1983-1987) i dziekanem Wydziału Prawa Kanonicznego KUL (1987-1989). Badania prowadzone przez ks. prof. dr. hab. Henryka Misztala dotyczyły zagadnień z zakresu prawa wyznaniowego i prawa kanonizacyjnego. W obu tych zakresach wypracował sobie pozycję autorytetu uznawanego nie tylko w Polsce, ale i za jej granicami. W pracach dotyczących prawa wyznaniowego szczególnie akcentował znaczenie należnej każdemu wolności religijnej. Natomiast w zakresie prawa kanonizacyjnego zasłynął przede wszystkim jako Autor całościowych opracowań prawa materialnego i procedury. Owocem pracy badawczej Księdza Profesora jest ponad 500 różnego rodzaju publikacji. Znakiem

* Ks. dr hab., prof. KUL, kierownik Katedry Prawa Wyznaniowego, Wydział Prawa, Prawa Kanonicznego i Administracji, Katolicki Uniwersytet Lubelski Jana Pawła II, Al. Racławickie 14, 20-950 Lublin, e-mail: piotr.stanisz@kul.pl. ORCID 0000-0002-2437-8513.

** Dr, Katedra Prawa Wyznaniowego, Wydział Prawa, Prawa Kanonicznego i Administracji, Katolicki Uniwersytet Lubelski Jana Pawła II, Al. Racławickie 14, 20-950 Lublin, e-mail: abrama@kul.pl. ORCID 0000-0002-1601-6969. 
docenienia Jego naukowych osiągnięć są przyznane Mu ordery i odznaczenia. Otrzymał m.in. Krzyż Kawalerski Orderu Odrodzenia Polski (2000) i Medal Komisji Edukacji Narodowej (2006). W 2018 r. został uhonorowany odnowieniem doktoratu przez macierzysty Uniwersytet. Na forum kościelnym obdarzono Go godnością kapelana honorowego Ojca Świętego Jana Pawła II (1996). Naukowa aktywność ks. prof. dr. hab. Henryka Misztala była stale inspirowana wiarą, pozostając nierozerwalnie związana z przeżywaniem kapłaństwa. Dopiero świadomość tego faktu pozwala właściwie zrozumieć nie tylko Jego życiowe wybory, ale i najgłębsze źródła autorytetu, którym się cieszył.

Słowa kluczowe: Henryk Misztal; prawo kanonizacyjne; prawo wyznaniowe; Katolicki Uniwersytet Lubelski Jana Pawła II

Abstract: The present study is dedicated to Rev. Prof. Henryk Misztal, who passed away on November 28, 2020. It aims to commemorate this distinguished scholar, engaged academic, tireless educator, and - moreover - a zealous priest and a good man. Prof. Misztal spent his entire academic career at John Paul II Catholic University of Lublin. For many years, he chaired the Department of Law on Religion and the Department of Canonization Law. He also carried a number of other important academic responsibilities, serving as vice-dean (1983-1987) and dean (1987-1989) of the Faculty of Canon Law at the Catholic University of Lublin. His research interests were in the areas of law on religion and canonization law. In both fields, he gained national and international recognition. His publications on law on religion especially highlighted the importance of religious freedom that is every person's right, whereas as a canonization law expert, he became best known as the author of comprehensive monographs devoted to substantive and procedural law. Over the course of his research, he contributed over 500 different kinds of publications. Prof. Misztal was repeatedly awarded for his research achievements. He received the Knight's Cross of the Order of Polonia Restituta (2000) and the Medal of the Commission of National Education (2006). In 2018, he was also honoured with the doctorate renewal ceremony at his University. On the Church forum, he was granted the title of Honorary Chaplain of His Holiness (1996). Prof. Misztal's research activity was constantly inspired by his faith and was inextricably connected with living his priesthood. Only when we are aware of that can we properly understand not only his life choices, but also the deepest sources of the authority that he enjoyed.

Key words: Henryk Misztal; canonization law; law on religion; John Paul II Catholic University of Lublin 
Mam ufność glęboka, że z grzechów uwolniony zostane przyjęty do Wiecznego Domu. Tam się ponownie wszyscy zobaczymy!

(H. Misztal, Promieniowanie kaptaństwa. Refleksje w Roku Kaptańskim, Lublin 2010, s. 131)

\section{WPROWADZENIE}

W dniu 28 października 2020 r. odszedł do Domu Ojca Ksiądz Profesor Henryk Misztal, wybitny uczony, zaangażowany i cierpliwy nauczyciel licznych rzesz studentów, niestrudzony wychowawca kolejnych pokoleń pracowników nauki. Pozostawił po sobie dzieła, które onieśmielają swą liczbą i znaczeniem. Aby je jednak w pełni zrozumieć, nie można poprzestać na uświadomieniu sobie wkładu ich Autora w naukę czy teoretycznego i praktycznego znaczenia prezentowanych w nich koncepcji. Konieczne jest uwzględnienie faktu oczywistego dla tych, którzy mieli szczęście poznać Go bliżej: Jego działalność naukowa była stale inspirowana wiarą, pozostając nierozerwalnie związana z przeżywaniem kapłaństwa. Dlatego do podanej na wstępie syntetycznej charakterystyki Księdza Profesora trzeba koniecznie dodać, że był gorliwym kapłanem Jezusa Chrystusa i człowiekiem konsekwentnie kształtującym swoją postawę w zgodzie z Ewangelią. Umiłował pełnię Prawdy, która znacząco wykracza poza świat przepisów prawnych i prawniczych formuł, w pełni je jednak obejmując. Dopiero świadomość tego faktu pozwala właściwie zrozumieć nie tylko Jego życiowe wybory, ale i najgłębsze źródła autorytetu, którym się cieszył.

\section{RYS BIOGRAFICZNY}

Ksiądz Profesor Henryk Misztal urodził się 10 kwietnia 1936 r. we wsi Skubicha (obecnie przysiółek Motycza) k. Lublina. Był synem Jana i Marianny z domu Anasiewicz. Na poziomie podstawowym uczył się w szkole powszechnej w Motyczu. Dalszą edukację pobierał w Lublinie, gdzie kształcił się najpierw w Gimnazjum, a następnie Liceum Biskupim przemianowanym na Niższe Seminarium Duchowne. Po zdaniu matury w Korespondencyjnym Liceum Ogólnokształcącym im. Wacławy Arciszowej 
w Lublinie, w latach 1954-1960 studiował na Wydziale Teologii KUL (Kurs A - Seminarium Duchowne). W dniu 18 kwietnia 1960 r. przyjął święcenia kapłańskie z rąk ks. bp. dr. Piotra Kałwy, a przez kolejny rok pracował jako wikariusz w parafii pod wezwaniem Najświętszej Maryi Panny w Tomaszowie Lubelskim ${ }^{1}$.

W 1961 r. ks. Henryk Misztal podjął studia specjalistyczne na Wydziale Prawa Kanonicznego KUL. Nie zaprzestał jednak aktywności duszpasterskiej, ucząc religii młodzież Liceum Chemicznego przy kościele powizytkowskim w Lublinie i angażując się w życie parafii Motycz. Magisterium i licencjat uzyskał w 1964 r. W 1968 r. nadano Mu stopień naukowy doktora prawa kanonicznego na podstawie rozprawy pt. Cenzura uprzednia pism i druków w Kościele Zachodnim. Studium historyczno-prawne, której promotorem był ks. prof. dr hab. Aleksy Petrani.

Pracę w Katolickim Uniwersytecie Lubelskim ks. dr H. Misztal rozpoczął w roku akademickim 1969/1970. Zatrudniony został jako asystent przy Międzywydziałowym Zakładzie Ustroju i Prawa PRL, którym kierował prof. dr hab. Wit Klonowiecki. W 1970 r. awansował na stanowisko adiunkta. Jednak w 1971 r., w związku ze śmiercią prof. W. Klonowieckiego, Międzywydziałowy Zakład Ustroju i Prawa PRL został zlikwidowany, a jego pracownicy zostali zwolnieni z pracy w Katolickim Uniwersytecie Lubelskim. Na szczęście już w kolejnym roku ks. dr H. Misztal został ponownie zatrudniony w KUL - tym razem jako starszy wykładowca w nowo utworzonej Katedrze Prawa Wyznaniowego² ${ }^{2}$ Dzięki otwartości prof. Hanny Waśkiewicz, kierującej pracami Katedry Praw Człowieka na Wydziale Filozofii Chrześcijańskiej, prowadził tam wówczas wykłady z różnych dziedzin prawa polskiego, a znakiem Jego zaangażowania $\mathrm{w}$ tę pracę są przygotowane wówczas publikacje o charakterze podręcznikowym: Postępowanie administracyjne (w: J. Grzywacz, H. Misztal, Wprowadzenie do Kodeksu rodzinnego i opiekuńczego. Postępowanie administracyjne, Lublin 1974) i Prawo cywilne. Skrypt dla studentów (Lublin 1975, mps BKUL).

Dnia 26 kwietnia 1979 r. ks. dr H. Misztal odbył kolokwium habilitacyjne. W przewodzie habilitacyjnym przedstawił rozprawę pt. „,Causae historicae" w postepowaniu beatyfikacyjnym $i$ kanonizacyjnym.

\footnotetext{
Zob. Stanisz 2018, 22-25.

2 Dębiński 2001, 43-44.
} 
Uchwała Rady Wydziału o nadaniu stopnia doktora habilitowanego, po jej zaaprobowaniu przez Senat Akademicki - zgodnie z obowiązującymi wówczas przepisami - została w 1980 r. zatwierdzona przez Ministra Nauki, Szkolnictwa Wyższego i Techniki. Dzięki temu ks. dr hab. Henryk Misztal uzyskał stanowisko docenta w Katedrze Prawa Wyznaniowego, a na wniosek ks. doc. dr. hab. Jerzego Grzywacza, dotychczasowego kuratora tej Katedry, został ustanowiony jej kierownikiem. Funkcję tę pełnił do końca 2007 r., w sposób decydujący przyczyniając się do rozwoju kierowanej jednostki.

W ciągu kilku kolejnych lat ks. doc. dr hab. Henryk Misztal wykładał na Wydziale Prawa Kanonicznego nie tylko prawo wyznaniowe - za którego dydaktykę w pełni odpowiadał - ale również prawo rodzinne i opiekuńcze, proces kanoniczny oraz czasy i miejsca święte. Angażował się ponadto w dydaktykę prowadzoną na Wydziale Teologii (Kurs A - Seminarium Duchowne, Sekcja Katechetyki). W 1984 r. został ponadto ustanowiony kuratorem utworzonej wówczas Katedry Prawa Kanonizacyjnego, prowadząc coraz liczniejsze zajęcia z prawa i postępowania beatyfikacyjnego (kanonizacyjnego). Dzięki Jego niezwykłemu zaangażowaniu Katedra ta stała się wiodącym ośrodkiem nauki prawa kanonizacyjnego w Polsce, zyskując duże uznanie również poza granicami naszego kraju ${ }^{3}$.

W 1986 r. ks. doc. dr hab. H. Misztal uzyskał awans na stanowisko profesora nadzwyczajnego. Natomiast po sześciu kolejnych latach, w 1992 r., został profesorem zwyczajnym.

Z biegiem lat Ksiądz Profesor coraz aktywniej angażował się w działalność macierzystego Wydziału Prawa Kanonicznego KUL. W 1983 r. został prodziekanem, a w 1987 r. wybrano Go na dziekana tej jednostki (funkcję tę pełnił do 1989 r.). Trzeba podkreślić, że był to czas intensywnego rozwoju Wydziału. Dynamicznie rozwijała się w szczególności funkcjonująca w jego ramach Sekcja Prawa, co znalazło odzwierciedlenie w zmianie nazwy Wydziału na Wydział Prawa Kanonicznego i Świeckiego. W trakcie swej pracy w KUL Ksiądz Profesor był również przewodniczącym Senackiej Komisji Dyscyplinarnej ds. Studenckich oraz członkiem wielu innych komisji senackich.

3 Zob. Fiejdasz 2008, 523-550. 
Ks. prof. H. Misztal wykładał także poza granicami Polski. W latach 1998-2002 prowadził zajęcia z prawa wyznaniowego i prawa kanonizacyjnego w ramach studium zorganizowanego przez KUL w Spiskiej Kapitule (Słowacja) i Ołomuńcu (Republika Czeska), a w latach 2003-2005 wykładał prawo wyznaniowe i konkordatowe na Wydziale Teologii Uniwersytetu Witolda Wielkiego w Kownie. Dwukrotnie (w 1986 r. i 1988 r.) był stypendystą Katolickiego Uniwersytetu Najświętszego Serca w Mediolanie.

Wszystkie lata swojej naukowej aktywności poświęcił Ksiądz Profesor Katolickiemu Uniwersytetowi Lubelskiemu Jana Pawła II. Powtarzał: „To jest mój i jedyny i umiłowany Uniwersytet” (Podziękowanie, w: Odnowienie Doktoratu Ks. Prof. Dr. Hab. Henryka Misztala, Lublin 2018, s. 54). Do 2011 r. był z tą Uczelnią związany stosunkiem pracy, oddając jej całość swojego zawodowego zaangażowania. Pomimo pojawiających się propozycji i potencjalnych profitów, również po 2011 r. wolał prowadzić zajęcia w KUL jako wolontariusz niż związać się inną uczelnią. Wzbogacał wówczas ofertę dydaktyczną Wydziału Prawa, Prawa Kanonicznego i Administracji o wykłady fakultatywne wygłaszane w języku włoskim na szczegółowe tematy z zakresu prawa kanonizacyjnego.

Ks. prof. H. Misztal pełnił ponadto odpowiedzialne funkcje w strukturach kościelnych. W macierzystej diecezji był notariuszem w Kurii Biskupiej, wykonywał funkcję sędziego w Sądzie Biskupim, pracował też jako archiwariusz, a następnie jako dyrektor w Archiwum Diecezjalnym Lubelskim. Sprawował również funkcję wizytatora archiwów parafialnych oraz wizytatora biskupiego. Był wieloletnim członkiem Kolegium Konsultorów, Rady Ekonomicznej, Rady Kapłańskiej oraz Komisji do Spraw Personalnych. Czynnie uczestniczył w różnych procesach beatyfikacyjnych i kanonizacyjnych. Prowadził 7 procesów polskich kandydatów na ołtarze zakończonych beatyfikacją. Sprawował też naukowy nadzór nad wieloma innymi procesami kanonizacyjnymi. Obdarzono Go wysokimi godnościami kościelnymi. W 1981 r. został kanonikiem honorowym Kapituły Katedralnej Lubelskiej, w 1992 r. - kanonikiem gremialnym Kapituły Metropolitalnej w Lublinie. W 1996 r. został obdarzony godnością kapelana honorowego Ojca Świętego Jana Pawła II.

Znakiem uznania dla osiągnięć i postawy Księdza Profesora są też państwowe wyróżnienia i odznaczenia, którymi został uhonorowany. W 2000 r. 
otrzymał Krzyż Kawalerski Orderu Odrodzenia Polski, w 2006 r. odznaczono Go Medalem Komisji Edukacji Narodowej, natomiast w 2009 r. przyznano Mu Złoty Medal za Długoletnią Służbę. Trzykrotnie otrzymywał nagrodę Rektora KUL (w 1981 r. - za pracę habilitacyjną; w 2000 r. „za oryginalne i twórcze osiągnięcia naukowe oraz kształcenie kadr naukowych"; w 2005 r. - za monografię: Le cause di canonizzazione. Storia e procedura, Città del Vaticano 2005). W 2007 r. został uhonorowany Medalem za Zasługi dla Katolickiego Uniwersytetu Lubelskiego Jana Pawła II, natomiast w 2017 r. otrzymał Medal 700-lecia Miasta Lublin. W dniu 6 czerwca 2018 r. odbyła się uroczystość odnowienia Jego doktoratu, co jest zaszczytem zarezerwowanym dla najwybitniejszych profesorów.

\section{WKŁAD DO NAUKI}

Badania naukowe prowadzone przez ks. prof. Henryka Misztala dotyczyły przede wszystkim dwóch różnych dyscyplin: prawa wyznaniowego i prawa kanonizacyjnego. Swoją przygodę naukową rozpoczął On jednak od badań dotyczących kościelnej cenzury uprzedniej pism i druków ${ }^{4}$. Wyniki odnoszących się do tego analiz, prowadzonych w związku z przygotowywaniem rozprawy doktorskiej, przedstawił m.in. w następujących artykułach naukowych: Cenzura uprzednia pism i druków w Kościele Zachodnim do soboru trydenckiego („Roczniki Teologiczno-Kanoniczne” 1973, z. 5, s. 101-113); Cenzura pism i druków w świetle obowiązujacego prawa („Summarium” 1973, s. 68-72); Kościelni cenzorzy ksiag („Roczniki Teologiczno-Kanoniczne" 1974, z. 5, s. 81-94); Kościelna cenzura wydawnictw w świetle dekretu „De Ecclesiae Pastorum vigilantia circa libros” („Roczniki Teologiczno-Kanoniczne” 1976, z. 5, s. 85-95). Po latach całościowe efekty badań z tego zakresu Ksiądz Profesor zebrał w monografii pt. Cenzura uprzednia pism i druków w Kościele Zachodnim (Lublin 2001). Na początkowych etapach swej naukowej aktywności zajął się On również kształtem duszpasterstwa Polonii włoskiej (Duszpasterstwo Polonii Włoskiej, w: Studia Polonijne, t. 1, Lublin 1976, s. 185-189) oraz sylwetką i dorobkiem ks. bp. prof. Jana Nowickiego (Profesor KUL - Ks. Jan Nowicki,

4 Dębiński 2001, 53-54. 
„Summarium” 1973, s. 279-282; Ks. Jan Nowicki, „Biuletyn Informacyjny KUL” 1974, nr 1-2, s. 279-282).

W latach 70. XX w. Ksiądz Profesor skierował zainteresowania naukowe na prawo kanonizacyjne i to jemu właśnie poświęcił przeważającą część swego naukowego zaangażowania (z czego specjaliści z zakresu prawa wyznaniowego nie zawsze w pełni zdają sobie sprawę). Problematyka prawno-kanonizacyjna zdecydowanie dominowała w badaniach prowadzonych przez Księdza Profesora do lat 90 . XX w. ${ }^{5}$ Po wymienionej wyżej rozprawie habilitacyjnej ukazały się: Drogi rozwoju postępowania kanonizacyjnego (Częstochowa 1983); Postępowanie kanonizacyjne (Warszawa 1985; we współautorstwie z J. R. Barem); Biegli w postępowaniu kanonizacyjnym (Lublin 1985) oraz Komentarz do Konstytucji apostolskiej „Divinus perfectionis magister” (Lublin 1987). Problematyka ta była też wyraźnie obecna w Jego późniejszych badaniach, czego dowodem są przede wszystkim następujące opracowania: Prawo kanonizacyjne wedtug ustawodawstwa Jana Pawła II. Instytucje kanonizacyjnego prawa materialnego. Zarys historii procedury kanonizacyjnej. Postępowanie w diecezji i Kongregacji. Wzory pism i formularzy (Lublin - Sandomierz 1997); Kanonizační právo podle zákonodárstwí Jana Pavla II. Instituce máterialního kanonizačního práva. Nástin dějin kanonizační procedury postup $v$ diecézi a v kongregaci vzory píisemností a formuláre (Olomouc 2002); Prawo kanonizacyjne. Instytucje prawa materialnego. Zarys historii. Procedura (Lublin 2003). Szczególne miejsce w dorobku naukowym Księdza Profesora zajmuje monografia: Le cause di canonizzazione. Storia e procedura (Città del Vaticano 2005), która została wydana przez wydawnictwo Stolicy Apostolskiej (Libreria Editrice Vaticana) i była rekomendowana przez Kongregację Spraw Kanonizacyjnych jako pomoc w prowadzeniu spraw kanonizacyjnych ${ }^{6}$. Wydanie tego dzieła bynajmniej nie oznaczało jednak zakończenia badań Księdza Profesora nad obowiązującym prawem kanonizacyjnym. W kolejnych latach ukazały się jeszcze dwie Jego książki dotyczące zagadnień prawno-kanonizacyjnych. Były to: ,Sanctorum Mater”. Instrukcja Kongregacji Spraw Kanonizacyjnych o prowadzeniu dochodzenia diecezjalnego lub eparchialnego w sprawach

Tamże, 47-52.

6 Zob. Fiejdasz 2008, 526-529. 
kanonizacyjnych. Komentarz (Lublin 2008 i 2011) oraz Postępowanie kanonizacyjne w diecezji lub eparchii (Lublin 2017; we współautorstwie z L. Fiejdasz-Buczek). Dzięki wymienionym monografiom, uzupełnionym o dziesiątki poważnych artykułów, Ksiądz Profesor wypracował sobie renomę czołowego znawcy prawa kanonizacyjnego, a lubelska Katedra Prawa Kanonizacyjnego, której był kuratorem, stała się prężnym ośrodkiem nauki prawa kanonizacyjnego, znanym szeroko poza granicami naszego kraju.

Uzupełnieniem wskazanych wyżej prac badawczych były opracowania odnoszące się do powszechnego powołania do świętości, a zwłaszcza książki: Świeccy święci i blogosławieni (Lublin 1992, Lublin - Sandomierz 2002); Anna Jenke (1921-1976) (Lublin 1994; we współautorstwie z B. Lipian); Geniusz kobiety. Aspekt etyczno-spoleczny (Sandomierz 1996, Częstochowa 2005) oraz Święci i my. Refleksje o osobach, które zachwycaja urokiem świętości (Lublin 2015). Ich lektura nie pozostawia wątpliwości, że fenomen świętości był dla Księdza Profesora nie tylko przedmiotem badań, ale też stanowił źródło prawdziwej fascynacji.

W latach 90. XX w. istotne miejsce w badaniach Księdza Profesora zajęło również prawo wyznaniowe. Impulsem do podjęcia badań z tego zakresu były przemiany demokratyzacyjne zachodzące w Polsce pod koniec wcześniejszego dziesięciolecia, które zdecydowały o nowym kształcie polskich przepisów dotyczących wolności religijnej oraz statusu kościołów i innych związków wyznaniowych, w tym zwłaszcza Kościoła Katolickiego. Pierwszym przedmiotem prowadzonych w tym zakresie analiz było ustawodawstwo wyznaniowe z 17 maja 1989 r. Komentując je jako jeden z pierwszych autorów, zwracał szczególną uwagę na jego zgodność z kościelną koncepcją wolności religijnej (Kościelne pojęcie wolności religijnej a ustawa o gwarancjach wolności sumienia i wyznania z 1989 r., „Kościół i Prawo” 1993, t. 11, s. 103-122; Ustawowe gwarancje wolności religijnej w Polsce od 1989 roku, „Chrześcijanin w Świecie” 1993, nr 3, s. 56-73; Wolność religijna w prawie polskim od 1989 r. (cz. I), ,Zamojski Informator Diecezjalny" 1994, nr 1, s. 47-54; Wolność religijna w prawie polskim od 1989 r. (cz. II), „Zamojski Informator Diecezjalny” 1994, $\mathrm{nr}$ 2, s. 120-140). Znaczenie tego ustawodawstwa docenił również z perspektywy czasu, poświęcając mu studium pt. Ustawy majowe - o gwarancjach wolności sumienia $i$ wyznania oraz o stosunku państwa do 
Kościoła Katolickiego w Polsce - z perspektywy 20 lat (w: Podstawy regulacji stosunków Państwo - Kościół w Rzeczypospolitej Polskiej i Republice Włoskiej. I fondamenti della regolazione delle relazioni Stato - Chiesa nella Repubblica di Polonia e nella Repubblica Italiana, red. P. Czarnek, D. Dudek, P. Stanisz, Lublin 2010, s. 85-107).

Mając świadomość zapotrzebowania na obiektywne opracowania z zakresu prawa wyznaniowego, które było dotkliwie odczuwalne w Polsce w latach 90. XX w., podjął Ksiądz Profesor również zadanie jego całościowego omówienia ${ }^{7}$. Swoją uwagę skierował przede wszystkim na stosunki istniejące między Państwem a Kościołem w okresie tzw. Polski Ludowej. Dokonując ich oceny, zgodnie z paradygmatem właściwym dla demokratycznych porządków prawnych, pytał w pierwszym rzędzie o stopień poszanowania wolności i praw należnych każdemu człowiekowi w związku z jego przyrodzoną godnością. Szczególnie akcentował przy tym potrzebę zagwarantowania każdemu wolności wyboru i uzewnętrzniania religii w zgodzie z postanowieniami umów międzynarodowych i nauczaniem Soboru Watykańskiego $\mathrm{II}^{8}$. Efektem prowadzonych w tym zakresie badań była publikacja pt. Polskie prawo wyznaniowe. Zagadnienia wstępne. Rys historyczny (Lublin 1996), która została pomyślana jako pierwszy tom obszerniejszego opracowania. Jak zasadnie stwierdzono w opublikowanej recenzji, dzięki umiejętnemu połączeniu przez Autora analiz teoretycznych z prezentacją faktów powstała praca „o ogromnej wartości poznawczej, poważnie przyczyniająca się do postępu wiedzy o dziejach stosunków państwo-Kościół w ogóle i w Polsce współczesnej"9.

Kontynuując prace nad całościowym omówieniem polskiego prawa wyznaniowego, Ksiądz Profesor skierował uwagę na przepisy obowiązujące współcześnie. Podlegały one wówczas intensywnym zmianom. Dnia 2 kwietnia 1997 r. uchwalona została Konstytucja Rzeczypospolitej Polskiej ${ }^{10}$, w której na nowo zdefiniowano polski model relacji państwo-Kościół, w obszernych przepisach gwarantując również poszanowanie

Zob. Abramowicz, Stanisz 2018, 163-167.

8 Zob. Dębiński 2001, 55-57.

9 Górowska 1997, 94-96. W podobnym tonie: Mezglewski 1997, 250-252.

10 Konstytucja Rzeczypospolitej Polskiej z dnia 2 kwietnia 1997 r., Dz. U. z 1997 r. $\mathrm{Nr} 78$, poz. 483 z późn. zm. 
wolności sumienia i religii. Z kolei 23 lutego 1998 r. ratyfikowano Konkordat między Rzecząpospolitą Polską i Stolicą Apostolską ${ }^{11}$, finalizując w ten sposób proces normalizacji stosunków między Państwem polskim a Kościołem Katolickim. Książka poświęcona tej problematyce została zatytułowana Prawo wyznaniowe III Rzeczypospolitej (Lublin - Sandomierz 1999), uwzględniając stan prawny na dzień 15 listopada 1998 r. ${ }^{12}$ Powstała ona pod redakcją i przy znaczącym udziale autorskim Księdza Profesora, który przygotował rozdziały pt. Wolność religijna i jej gwarancje prawne, Osobowość prawna kościołów i innych zwiazków wyznaniowych oraz Prawo małżeńskie. Jego zasługą było również skupienie wokół tego dzieła nie tylko współpracowników z Wydziału Prawa Kanonicznego i Świeckiego KUL (a zwłaszcza z Katedry Prawa Wyznaniowego), lecz także uznanych autorów spoza tego środowiska.

Omówione wyżej publikacje stały się następnie podstawą całościowego opracowania pt. Prawo wyznaniowe (red. H. Misztal, Lublin - Sandomierz 2000). Również tym razem pracę redakcyjną wykonał ks. prof. H. Misztal, który był ponadto Autorem większości tekstów (spod Jego pióra wyszły w całości dwie pierwsze części: Zagadnienia wstępne i Historia relacji państwa do kościołów i innych związków wyznaniowych w Polsce, natomiast w ramach części III pt. Obowiąujące polskie prawo wyznaniowe opracował następujące rozdziały: Wolność religijna, Osobowość prawna kościołów i innych związów wyznaniowych oraz Prawo matżeńskie). Podczas przygotowania nowej publikacji nie ograniczono się do połączenia wydanych wcześniej tekstów. Z myślą o potrzebach studentów przyjęto nową strukturę opracowania, w sposób bardziej syntetyczny ujęto zagadnienia o charakterze historycznym, zaktualizowano fragmenty dotyczące prawa obowiązującego współcześnie oraz dodano teksty kompletujące całościową wiedzę na temat polskiego prawa wyznaniowego. W wydawniczych recenzjach tego opracowania zwrócono uwagę, że ma ono nie tylko „wartościowe cechy prawniczej pracy naukowej”, ale nadto uwzględnia aksjologiczny wymiar poruszanych problemów

11 Konkordat między Stolicą Apostolską i Rzecząpospolitą Polską podpisany dnia 28 lipca 1993 r., Dz. U. z 1998 r. Nr 51, poz. 318.

12 Recenzje tej pracy opublikowali: Pietrusiński 1999, 433-444 oraz Górowska 1999, 88-89. 
(W. Łączkowski), wychodząc ,naprzeciw zapotrzebowaniu, jakie na rynku wydawniczym istnieje na książki i publikacje, które pokazują problematykę stosunków wyznaniowych szerzej pojętych, zaprezentowaną m.in. na gruncie doktryny Kościoła oraz katolickich postulatów ustrojowych i prawnych, nie zaś tylko na gruncie ciasnej doktryny pozytywizmu prawniczego" (M. Granat) ${ }^{13}$. Po trzech latach omawiane opracowanie doczekało się drugiego wydania (Prawo wyznaniowe, red. H. Misztal, P. Stanisz, Lublin - Sandomierz 2003) ${ }^{14}$.

Odpowiedzią na kolejne zmiany zachodzące w polskim prawie wyznaniowym oraz zmieniające się potrzeby dydaktyczne była decyzja o przygotowaniu zupełnie nowego podręcznika akademickiego. W jego opracowywaniu Ksiądz Profesor uczestniczył jako jeden z autorów, wspierając swych młodszych współpracowników. Jest przy tym jasne, że bez Jego udziału powstały wówczas podręcznik (A. Mezglewski, H. Misztal, P. Stanisz, Prawo wyznaniowe, Warszawa 2006, 2008, 2011) miałby dużo mniejsze szanse powodzenia.

Oprócz podejmowania prac skierowanych na przygotowanie kolejnych całościowych ujęć polskiego prawa wyznaniowego prowadził Ksiądz Profesor badania mające na celu wyjaśnienie szczegółowych problemów zauważalnych na gruncie obowiązujących wówczas przepisów. Do najważniejszych nurtów badawczych należała realizacja wolności religijnej w ramach rodziny. W publikacjach dotyczących tego zagadnienia podkreślał znaczenie prawa rodziców do decydowania o kierunku religijnego wychowania potomstwa, zwracając jednocześnie uwagę na potrzebę należytego poszanowania wolności samych dzieci. Tej problematyce zostały poświęcone następujące opracowania: Prawa rodziny $w$ zakresie religijnego wychowania dzieci (w: Katecheza dzisiaj. Problemy prawne i teologiczne, red. W. Janiga, A. Mezglewski, Krosno - Sandomierz 2000, s. 13-31); Gwarancje prawa międzynarodowego i polskiego w zakresie uprawnień rodziców do religijnego wychowania dzieci („Studia z Prawa Wyznaniowego" 2000, t. 1, s. 5-20); Prawo rodziców do wychowania dzieci (w: Iustitia civitatis fundamentum. Księga pamiątkowa ku czci Profesora Wiesława Chrzanowskiego, red. H. Cioch, A. Dębiński, J. Chaciński,

13 Recenzję tej pracy opublikował Tymosz 2000, 229-232.

14 Zob. Stanisz 2018, 30-32. 
Lublin 2003, s. 555-571); Wolność rodziców do wychowania religijnego i moralnego dzieci zgodnie z ich przekonaniami („Przegląd Prawno-Ekonomiczny" 2012, nr 4, s. 6-13).

Sporo uwagi w swych badaniach ks. prof. H. Misztal poświęcił sytuacji prawnej uniwersytetów katolickich, zwracając szczególną uwagę na ich zadania oraz wolność należną zarówno takim jednostkom, jak i związanym z nimi naukowcom (Wizja KUL Kardynała Stefana Wyszyńskiego, „Zeszyty Naukowe KUL” 1995, nr 1-2, s. 89-107; Wolność uniwersytetu i na uniwersytecie katolickim, „Studia z Prawa Wyznaniowego” 2002, t. 4, s. 3-30; Uniwersytet katolicki w doktrynie Kościoła i prawie kanonicznym, w: Ius et lex. Ksiega jubileuszowa ku czci Profesora Adama Strzembosza, red. A. Dębiński, A. Grześkowiak, K. Wiak, Lublin 2002, s. 425-445; Priorytety katolickich uczelni w XXI wieku, w: Reddite ergo quae sunt Caesaris Caesari et quae sunt Dei Deo. Ksiega Jubileuszowa dedykowana Księdzu Profesorowi Józefowi Krukowskiemu z okazji 50-lecia pracy naukowej, red. M. Sitarz, P. Stanisz, H. Stawniak, Lublin 2014, s. 471-487). Natomiast w publikacjach dotyczących archiwów kościelnych podkreślał ich znaczenie dla gromadzenia, opracowywania i udostępniania zbiorów dziedzictwa narodowego i kościelnego, analizując nie tylko przepisy prawa polskiego, ale i unormowania o charakterze prawno-kanonicznym (Sytuacja prawna archiwum parafialnego, „Archiwa, Biblioteki i Muzea Kościelne" 2001, s. 77-90; Sytuacja prawna archiwum parafialnego, „Roczniki Nauk Prawnych” 2002, t. 12, z. 2, s. 87-102; Archiwum Diecezjalne, w: Struktura i zadania Kurii Diecezjalnej. Materiały z ogólnopolskiej konferencji naukowej zorganizowanej w ramach obchodów Roku Prymasa Tysiaclecia przez Stowarzyszenie Kanonistów Polskich, Wydziat Prawa Kanonicznego UKSW, Wydziat Nauk Prawnych TNKUL oraz Wyzsze Seminarium Duchowne w Diecezji Warszawsko-Praskiej (Warszawa - Praga 11-12.9.2001), red. J. Krukowski, K. Warchałowski, Warszawa 2003, s. 103-117). Oprócz tego - również w osobnych opracowaniach, a nie tylko w powołanych wyżej całościowych omówieniach polskiego prawa wyznaniowego - zajmował się Ksiądz Profesor problematyką kościelnych osób prawnych (Kościelne osoby prawne w prawie polskim, w: Historia et ius. Księga pamiatkowa ku czci ks. prof. Henryka Karbownika, red. A. Dębiński, G. Górski, Lublin 1998, s. 491-513) oraz wybranymi aspektami prawa wyznaniowego okresu tzw. Polski Ludowej (Divide 
et impera. Niszczenie struktur kościelnych i represje wobec duchownych w Polsce jako jedna z metod walki systemu stalinowskiego z religia, w: Represje wobec osób duchownych i konsekrowanych $w$ PRL $w$ latach 1944-1989, red. A. Grześkowiak, Lublin 2004, s. 23-43; Zarys kompetencji, styl działania i cele Urzędu do Spraw Wyznań, w: Prawo i polityka wyznaniowa w Polsce Ludowej. Materiaty z II Ogólnopolskiego Sympozjum Prawa Wyznaniowego (Kazimierz Dolny 26-28 października 2004), red. A. Mezglewski, P. Stanisz, M. Ordon, Lublin 2005, s. 33-70; we współautorstwie z A. Mezglewskim).

Przedmiotem zainteresowań badawczych Księdza Profesora stała się także historia lokalnej społeczności, z której się wywodził, ze szczególnym uwzględnieniem roli Kościoła oraz duchowieństwa. Tej problematyce zostały poświęcone opracowania monograficzne, które redagował i w których tworzeniu uczestniczył jako Autor (W Duchu i Prawdzie. Wybrane sylwetki Kościoła lubelskiego, red. H. Misztal, Lublin 2005; Motycz - nasza ojczyzna, red. H. Misztal, Motycz 2005; Motycz. Więzi pokoleń, red. H. Misztal, Motycz 2009). Natomiast w ostatnim czasie dokonał charakterystyki prześladowań chrześcijan we współczesnym świecie, koncentrując się na państwach muzułmańskich. Identyfikując przyczyny i skutki tych prześladowań, sformułował również wynikające stąd postulaty (Geografia prześladowań chrześcijan w krajach islamskich, „Studia z Prawa Wyznaniowego" 2014, t. 17, s. 91-110; Prześladowanie chrześcijan $w$ krajach islamskich, w: Aktualne problemy wolności myśli, sumienia i religii, red. P. Stanisz, A. M. Abramowicz, M. Czelny, M. Ordon, M. Zawiślak, Lublin 2015, s. 213-227).

Naukowy dorobek ks. prof. H. Misztala obejmuje w sumie ponad 500 pozycji. W tej liczbie są 42 publikacje książkowe, ponad 170 artykułów naukowych i ok. 80 artykułów popularyzujących naukę, 20 haseł encyklopedycznych, blisko 39 biogramów, ponad 50 recenzji, ponad 30 przekładów oraz wiele innych publikacji. Wyniki swoich badań wielokrotnie prezentował On również na konferencjach naukowych w kraju i za granicą ${ }^{15}$.

15 Kompletny wykaz publikacji Księdza Profesora Henryka Misztala jest dostępny na stronie: http://www.kul.pl/ks-prof-dr-hab-henryk-misztal,art_1099.html 


\section{DZIAŁALNOŚĆ ORGANIZACYJNA I KSZTAŁCENIE KADR}

Ksiądz Profesor Henryk Misztal odegrał również istotną rolę w organizacji życia naukowego oraz w kształceniu młodszych pracowników nauki ${ }^{16}$. Łatwo to dostrzec zarówno w zakresie prawa kanonizacyjnego, jak i prawa wyznaniowego. Katedra Prawa Kanonizacyjnego, której był kuratorem, organizowała cykliczne konferencje naukowe dotyczące różnych aspektów świętości kanonizowanej, a On sam - jako delegat biskupi - prowadził sprawy 7 polskich kandydatów na ołtarze, służąc różnoraką pomocą w innych polskich procesach beatyfikacyjnych i kanonizacyjnych. Spory jest również wkład Księdza Profesora w integrację polskiego środowiska specjalistów z zakresu prawa wyznaniowego. Kierowana przez Niego Katedra Prawa Wyznaniowego była m.in. - z inicjatywy ks. Artura Mezglewskiego - gospodarzem trzech pierwszych ogólnopolskich zjazdów katedr i wykładowców prawa wyznaniowego, które dały początek spotkaniom organizowanym corocznie do czasów obecnych. Ksiądz Profesor miał też poważny wkład w utworzenie Polskiego Towarzystwa Prawa Wyznaniowego. Był jednym z inicjatorów jego powstania, a wśród członków-założycieli znaleźli się Jego uczniowie. Wsparł również inicjatywę powołania czasopisma „Studia z Prawa Wyznaniowego", które szybko stało się forum ogólnopolskiej debaty naukowej.

Pisząc o wkładzie ks. prof. H. Misztala do nauki prawa nie sposób nie wspomnieć o osiągnięciach osób, które przeszły przez prowadzone przez niego seminaria magisterskie i doktoranckie, a następnie - dzięki uzyskanemu przygotowaniu - kontynuowały samodzielną pracę naukową. Pod Jego kierunkiem przygotowano ponad 170 prac licencjackich i magisterskich, a stopień doktora nauk prawnych w zakresie prawa lub prawa kanonicznego uzyskało ponad 30 osób (rozprawy z zakresu prawa wyznaniowego przygotowali: T. M. Bach, A. Mezglewski, J. Dziobek-Romański, P. Stanisz, T. Stanisławski, F. Jurčišin, F. Długoš, I. A. Hrdina, L. Kowalenko, B. Uliasz, A. Tunia, M. Ordon, W. Wnuk, F. Zehnal i D. Mazurkiewicz). Ksiądz Profesor przygotował też ponad 80 recenzji w różnego rodzaju postępowaniach awansowych ${ }^{17}$.

16 Zob. Abramowicz, Stanisz 2018, 167-171.

17 Zob. odnoszące się do tego wykazy: Fiejdasz 2009a, 739-752; Fiejdasz 2009b, 753-759; Ordon 2001, 33-40. 
W okresie ponad 25 lat kierowania przez ks. prof. dr. hab. Henryka Misztala Katedrą Prawa Wyznaniowego uzyskała ona pozycję ważnego ośrodka nauki prawa wyznaniowego w Polsce. Zdecydowało o tym wyjątkowe zaangażowanie Księdza Profesora nie tylko jako naukowca i promotora, ale też jako lidera, który potrafił skupić grupę młodszych pracowników nauki wokół realizacji wspólnych inicjatyw. Nie ograniczał przy tym rozwoju indywidualnych zainteresowań, chociaż konsekwentnie wpajał przekonanie o konieczności należytego uwzględnienia takich wartości, jak godność człowieka i zakorzenione w niej prawa i wolności (a wśród nich wolność religijna) oraz dobro wspólne.

\section{KONKLUZJE}

Na pełne zrozumienie znaczenia ideałów, które Ksiądz Profesor wyznawał i które starał się wpajać innym, pozwala dopiero uwzględnienie właściwej $\mathrm{Mu}$ perspektywy wiary. Swoje uniwersyteckie zaangażowanie postrzegał wszak w kategoriach „wielkiej przygody z nauką inspirowaną wiarą" (Przemówienie wygłoszone podczas uroczystości wręczenia Księgi Jubileuszowej, w: Religioni et scientiae. Materiały V Sympozjum Prawa Kanonizacyjnego (Lublin, 25 kwietnia 2001 r.), red. P. Stanisz, Lublin 2001, s. 226). Wspomniane ideały obejmowały więc nie tylko niestrudzone dążenie do Prawdy, ale też konsekwentną służbę na rzecz dobra człowieka i dobra wspólnego. Są to niewątpliwie wartości zajmujące ważne miejsce w niespisanym, naukowym testamencie Księdza Profesora.

\section{BIBLIOGRAFIA}

Abramowicz, Aneta, Piotr Stanisz. 2018. „Katedra Prawa Wyznaniowego”. W: 100 lat nauk prawnych na Katolickim Uniwersytecie Lubelskim Jana Pawła II, red. Krzysztof Burczak, Emilia Czepczyńska, Marzena Dyjakowska, Maciej Jońca, Sebastian Kwiecień, 149-180. Lublin: Wydawnictwo KUL.

Dębiński, Antoni. 2001. „Wkład Księdza Profesora Henryka Misztala do nauki prawa". W: Divina et humana. Ksiega Jubileuszowa w 65. rocznice urodzin 
Księdza Profesora Henryka Misztala, red. Antoni Dębiński, Wiesław Bar, Piotr Stanisz, 43-60. Lublin: Redakcja Wydawnictw KUL.

Fiejdasz, Lidia. 2008. „Katedra Prawa Kanonizacyjnego”. W: Księga Jubileuszowa z okazji 90-lecia Wydziatu Prawa, Prawa Kanonicznego i Administracji Katolickiego Uniwersytetu Lubelskiego Jana Pawła II, red. Antoni Dębiński, Małgorzata Ganczar, Stanisław Jóźwiak, Agnieszka Kawałko, Małgorzata Kruszewska-Gagoś, Hanna Witczak, 523-550. Lublin: Wydawnictwo KUL. Fiejdasz, Lidia. 2009a. „Prace dyplomowe napisane pod kierunkiem Księdza Profesora Henryka Misztala". W: Henryk Misztal. Duc in altum. Sprawy kanonizacyjne. Wybór pism, red. Lidia Fiejdasz, 739-752. Lublin: Wydawnictwo KUL.

Fiejdasz, Lidia. 2009b. „Recenzje doktorskie, habilitacyjne oraz do tytułu profesora". W: Henryk Misztal. Duc in altum. Sprawy kanonizacyjne. Wybór pism, red. Lidia Fiejdasz, 753-759. Lublin: Wydawnictwo KUL.

Górowska, Beata. 1997. „Ks. Henryk Misztal: Polskie prawo wyznaniowe. Zagadnienia wstępne. Rys historyczny, tom 1, Lublin 1996, Wyd. KUL, ss. 374”. Państwo i Prawo 1: 94-96 (rec.).

Górowska, Beata. 1999. „H. Misztal (red.), Prawo wyznaniowe III Rzeczypospolitej, Lublin-Sandomierz 1999”. Państwo i Prawo 11: 88-89 (rec.).

Mezglewski, Artur. 1997. „Polskie prawo wyznaniowe, cz. I: Zagadnienia wstępne. Rys historyczny, Lublin 1996". Roczniki Nauk Prawnych 7: 250-252 (rec.).

Ordon, Marta. 2001. „Wykaz prac dyplomowych”. W: Divina et humana. Księga Jubileuszowa w 65. rocznice urodzin Księdza Profesora Henryka Miszta$l a$, red. Antoni Dębiński, Wiesław Bar, Piotr Stanisz, 33-40. Lublin: Redakcja Wydawnictw KUL.

Pietrusiński, Dionizy. 1999. „H. Misztal (red.), Prawo wyznaniowe III Rzeczypospolitej, Lublin-Sandomierz 1999". Wiadomości Archidiecezji LubelskiejMemoranda, dicta et facta 2: 433-444 (rec.).

Stanisz, Piotr, 2018. „Laudacja z okazji uroczystości odnowienia doktoratu ks. prof. Henryka Misztala”. W: Odnowienie Doktoratu Ks. Prof. Dr. Hab. Henryka Misztala, 21-36. Lublin: Wydział Prawa, Prawa Kanonicznego i Administracji KUL.

Tymosz, Stanisław. 2000. „Prawo wyznaniowe. Stan prawny na 1 lutego 2000, ss. 509. Wydawnictwo Diecezjalne w Sandomierzu". Zamojski Informator Diecezjalny 2: 229-232 (rec.). 
